\title{
Authority of Village-Owned Business Entity (Bumdesa) in Village Forest Management at Selat Village Buleleng Regency
}

\author{
I Wayan Wesna Astara ${ }^{1}$, Ketut Widia ${ }^{2}$, I Wayan Rideng ${ }^{3}$ \\ Master of Law Program, Universitas Warmadewa, Denpasar, Indonesia ${ }^{1,2,3}$ \\ $\left\{\right.$ suarjana66.acc@gmail.com $\left.{ }^{1}\right\}$
}

\begin{abstract}
Community participation both in policy and management of forest resources is very important to prevent and overcome forest destruction. As one of the government policies is to restore local communities as the main role of forestry development through Social Forestry policy. According to the village community, the Selat forest is considered as a source of water springs, a source of livelihood, a natural tourist area, and it has spiritual values that are respected by the community. The problems formulated in this study were how the legal protection and how the effectiveness of BUMDesa (village-owned business entity) in managing village forests at Selat Village of Buleleng Regency. The type of this research is a mixed legal research. The results of this study lead to a conclusion that the protection of village forests was carried out preventively and repressively. The effectiveness of BumDesa's authority on village forest management has not been effectively implemented in accordance with the Village Forest Rights and Management Work Plan and legislation that applies both state law and customary law. It is caused by the unavailability of adequate human and capital resources for the management of all village forest areas.
\end{abstract}

Keywords: Protection; Social Forestry; Conservation of Village Forests

\section{Introduction}

Forest is a national development capital that has ecological, economic and socio-cultural benefits. In the Law No. 41 of 1999 regarding Forestry, it states that a forest is an ecosystem unit in the form of a stretch of land consisting of biological natural resources that dominated by trees which has three functions namely conservation function, protection function, and production function. Along with the increasing rate of forest conversion which is estimated reaching 2 (two) million hectares per year for agricultural land, settlements, and fulfillment of various community needs, it is realized that it has reduced area and function of forest which causes many problems such as ecological system damage, flora and fauna extinction, flooding, drought, and even global climate change.

Increasing community participation both in policies and also in management of forest resources can prevent and overcome forest destruction. Recognition of the importance of society as the basis for forestry development in Indonesia is embodied in a paradigm shift which is then manifested in various forms of policy. One of the important policies that can be 
a reflection of the government's willingness to restore local communities as the main actor in forestry development in Indonesia is the Social Forestry policy.

Social forestry policies provide real opportunities for communities inside and around of forest areas. This can be conducted by giving an access rights, and in forest development and management, the community are positioned as the main actor. In accordance with Law No. 41 of 1999 regarding forestry, clearly explained that the empowerment of local communities in and around forests is carried out in order to strengthen community institutions in forest utilization. In addition, social forestry development is a form of implementation of decentralization policies in the forestry sector, the role of regional governments, especially the district/city government. Then, this become very important because all technical aspects of program implementation will be responsibility of the central government and regional government.

Licensing of social forestry is not the end of the process of community empowerment to achieve the goals of community welfare. After obtaining a social forestry permit, the stages need to be strengthened by the parties to empower communities around the forest. This means that achieving the licensing target in social forestry programs is not a truly single indicator to measure the success of the program. The holders of village forest licenses in the economic field as a beneficial aspect are also important to be considered.

Meanwhile, for the people of Selat Village in Sukasada Subdistrict, Buleleng Regency, Bali Province, forests are considered as a source of water, a source of livelihood, a potential natural tourism area, and have magical values that are highly respected by the community.

Given the strategic function of forests for the preservation of nature for the benefit of humanity, there are various efforts conducted to maintenance both preventive by giving decisive actions, by providing an understanding to the public about the importance of preserving forests and strictly prohibiting people from entering the protected forest areas for hunting or farming purposes within forest areas.

On the basis of the legal provisions above, specifically, the indigenous village community of Pandan Banten Strait located in Selat Village, Sukasada sub-district, Buleleng Regency, Bali Province has the opportunity to participate in managing state forests. Various efforts were made by the Selat village community to obtain the intended legality, and the end the government agreed to the request of the Selat village community to manage state forests and be made into village forests in accordance with Selat Village Regulation Number 1 of 2011 concerning Village Forests. In the context of state forest management by the Selat Village Government, a Village-Owned Enterprise (BUMDesa) was formed "Pandan Harum". The establishment of BUMDesa "Pandan Harum" at Selat Village facilitated by the Buleleng Regency Forestry and Plantation Service led by chairman and vice chairman Ketut Mangku and Wayan Diarka through Selat Village Regulation Number 2 of 2011 concerning Guidelines for establishing village-owned business. The next explanation would be pertained some preceding study related to current issue.

Firstly, a research done by (Borgias, 2018). In this article, it has been shown how social movement actors respond to and fill the absence of the state in its regulatory role in the context of the socio-environmental conflict triggered by the Alto Maipo hydroelectric project in central Chile. Despite a lot of social controversies, Alto Maipo has been supported by a strong network of companies dealing with water, energy, and mining interests. The Chilean government has facilitated the course of the project through political action and regulatory inaction, reflecting the role of the state being restructured under the neoliberal institutional order imposed during the Pinochet regime. In this setting, social movement actors, as 
intermediary groups, bear the burden of filling regulatory gaps, supervising companies, and holding governments to account for environmental regulations.

Secondly, a research conducted by (Soltani, Sankhayan, \& Hofstad, 2016). This study employed three analytical approaches, namely goal programming, non-cooperative games, and bargaining games which have been used to study strategic interactions between the state and local communities. The results showed that the current situation in the Zagros study area in Iran where logging is prohibited on a de jure basis although some illegal charcoal production by villagers still exists. It is very close to the Nash balance discovered in the bargaining game. However, the dominant strategic balance found in the non-cooperative play is far from that found in ordinary business. This suggests that even though there is no formal agreement between the state authorities and local community members, the game structure between the state and local communities in northern Zagros tends to be cooperative.

Thirdly, research conducted by (Kan, 2016). The results showed that villages have collectively been preserved and reconsolidated through reform and revitalization of inherited institutional arrangements, and through shareholding reforms and subsequent corporatization.

The collective examination of villages in China's urbanization not only describes the structures and processes that have contributed to its continued vitality but also produces insights into how "village" or "rural" should be implemented in the context of rapid administrative, economic and territorial transformation.

Based on the description above, the subject matter that will be further investigated can be identified as follows (1) How is the legal protection for village forests in Selat Village of Buleleng Regency? (2) How is the effectiveness of the authority of Village-Owned Business Entity (BUMDesa) in managing village forests in Selat Village of Buleleng Regency?

\section{Method}

The types of research used in this study are normative legal research and empirical legal research types. This type of mixed legal research is called as a type of participatory legal research, or collaboration of two types of legal research (Susanto, 2015). Particularly, the research location is at Selat Village, Sukasada Sub-district, Buleleng Regency, which has a protected forest with an area of \pm 552 hectares spread in several hamlets in the Selat Village.

\section{Results and Discussion}

\subsection{The Legal Protection on the Village Forests at Selat Village of Buleleng Regency.}

Basic legal protection of village authority in the management of village forest areas is regulated in Article 5 Paragraph 1 of Law Number 41 of 1999 regarding forestry, which regulates community empowerment in state forest areas. Furthermore, legal protection for village forests is regulated in the Minister of Environment and Forestry Regulation Number P.83/MENLHK/SETJEN/KUM.1/10/2016 concerning Social Forestry. Social forestry is a sustainable forest management system that is implemented in state or customary forests by local or customary communities to increase welfare, environmental balance, and socio-cultural dynamics in the form of Village Forests, Community Forests, Community Forests Plantation, Customary Forest, and Forestry Partnership. 
This Ministerial Regulation is made to formulate guidelines on management rights, permits, partnerships, and customary forests in the social forestry sector. This Ministerial Regulation functions to resolve issues of control and justice (land) for local communities and indigenous peoples who live in or around forest areas in the context of community welfare and forest function preservation.

In addition, the authority of the provincial and district governments is based on the Bali Governor's Decree Number 2017/03-L / HK / 2015 regarding the Granting of Village Forest Management Rights to Village Protected Forest Areas in Buleleng Regency. Legal protection of village forests is also regulated in the Decree of the Governor of Bali Province Number 75 of 2018 concerning Social Forestry. In Regional Regulation Number 16 of 2009 concerning the Spatial Plan for the Province of Bali for 2009-2029 it is regulated in Article 43 that protected areas include protected forest areas and water absorption areas.

The Guidance, control, and supervision of village forest management are also regulated in an Awig-Awig (customary law) of the Banten Village of Pandan Selat, according to what is stated in Sargah VI (Part 6) of the Pawos 71 Forest Village (Article 71) Indic Alas (concerning the forest).

With this affirmation in the legislation, it shows that the government has actually provided protection for the existence of natural resources in general or forest resources in particular. The existence of a protected forest in Selat Village before being managed by BUMDesa, its condition is very alarming due to hunting, theft of timber and non-timber forest products, encroachment, and land grabbing by community members around protected forest area. This causes disruptions of forest habitats and ecosystems that have an impact on the environment around and outside protected forest areas such as flash floods, erosion, and drought.

The theory of legal certainty proposed by Soedikno Mertokusumo related to the control of illegal logging and forest clearing by law enforcers to protect village forest areas in the Selat Village, which can be said as a protection on the existence of village forest areas and the rights of the community to benefit, maintain, or obtain income from the sector. But surely, this depends on law enforcement officials to enforce the legislation and the justice in the community in the village forest area.

\subsection{The Effectiveness of the Authority of Village-Owned Business Entity (BUMDesa) in the Management of Village Forests at Selat Village of Buleleng Regency.}

The Village-Owned Enterprises (BUMDes) implementation is mandated by Law Number 6 of 2014 regarding Villages. In carrying out the implementation of BUMDesa, it certainly has a clear legal basis so that there is clarity of purpose and to be more organized in its implementation and management. The following are a number of laws and government regulations and other regulations that mandate and regulate implementation of BUMDesa.

From the description above, it can be understood that Law Number 6 of 2014 concerning Villages mandates that every Regional Government in the unitary state of the Republic of Indonesia explores its potential both in general and in the smallest area. The Regional Government issues a legal product, namely Regional Regulation Number 10 of 2015 concerning Procedures for the Construction and Management of BUMDesa.

The village administration, by looking at the various potentials in Selat Village, makes a regulation on BUMDesa that is Selat Village Regulation Number 3 of 2012 concerning Village-Owned Business Entity (BUMDesa) "Pandan Harum", then explained in Chapter III the type and business development. The BUMDesa business activities listed in Article 13 Paragraph (1) states that the management of village forest working areas in the form of area 
utilization, environmental service utilization, and non-timber forest products utilization as business capital is in accordance with the work plan and agro-tourism development.

The various laws and regulations above are the main foundation in the execution and management of BUMDesa, especially in the Selat Village Buleleng Regency, which formally regulates both general and technical aspects. The BUMDesa management is expected to be carried out according to the mandate of the Law and other Regulations so that the economy of rural communities can develop evenly, and the role of village government is certainly needed in the management of BUMDesa as the person in charge of village economic conditions.

Furthermore, village authority includes the authority of village administration, village community development, implementation of village development, and empowerment of village communities based on community initiatives, proposals for native rights, and village customs. This is regulated in Law Number 6 of 2014 concerning Villages and Article 18 of the Village Law. In addition, Article 19 of Law Number 6 of 2014 concerning Villages regulates village authority including authority built on village-scale regional authority, rights of origin, the authority determined by the district/city government, provincial government, or government; and other authorities assigned by the government, provincial government, or district/city government.

The regulation and confirmation of village rights over natural resources are regulated as well in Article 371 paragraph (2) of Law Number 23 of 2014 concerning the Regional Government, that villages have the authority in accordance with the provisions of laws and regulations on villages. Based on various laws and regulations mentioned, it can be concluded that the village community normatively has the right to the management of village-scale natural resource with the intention of realizing the welfare of rural communities, one of them can be carried out by BUMDesa. In connection with the aforementioned discussion, it has been clearly described the authority of Village Government (in this case) Selat Village government, Regency/City Government, Provincial Government, and the government, to protect the village forest area. Judging from the theory of authority presented by Philipus M. Hadjon stated that every government action is considered based on legitimate authority. Authority can be achieved from three sources; they are mandate, delegation, and attribution.

From the three sources of authority, based on the researcher's opinion, the authority in granting and applying for rights or permits and the implementation of forestry partnerships and protection of village forest areas are the authority of delegations obtained by Bali Provincial Government because such authority is directly obtained from legislation.

It is very important in the village forest management model by BUMDesa and traditional village-based institutions in maintaining the preservation of village forests with the formation of supervisory staff before the Awig-Awig in the form of Jagawana Pecalang. In order to protect and prevent the destruction of village forests from irresponsible parties, both those carried out by community members or community from outside the village forest area. The existence of Pecalang who are supervising or maintaining village forest areas is not sufficient enough considering the area of village forest is around \pm 552 hectares with a number of 15 new Pecalang to supervise and maintain the village forest area from possible violations in the village forest area.

The problems currently faced by the management of BUMDesa and traditional villages as village forest managers in implementing village forest utilization are the unavailability of adequate human and capital resources for the management of all village forest areas. An assistance from a continuous technical agency is needed to facilitate village forest actors or managers to consult on sustainable village forest management patterns. The absence of an 
appropriate and efficient marketing scheme for marketing village forest products, both nontimber products and ecotourism services.

\section{Conclusions}

Based on the description of the discussion and the analysis carried out on the formulation of the problem, conclusions are made as follows:

a. Legal protection against the existence and preservation of village forests in the Selat Village area of Buleleng Regency is carried out preventively by conducting an active and continuous supervision on regulations without involving concrete events which raises the presumption that legislation both state law and customary law has been violated. Repressive law enforcement is carried out in the case of violating the rules and aims to end directly the prohibited acts that cause damage in the village forest area in the Selat village. The basis for the implementation of village forest protection comes from the provisions of these legislations:

1. Law Number 41 of 1999 concerning Forestry,

2. Regulation of Minister of Environment and Forestry Number P.83/MEN/LKH/ SETJEN/KUM.1/10/10/2016 concerning Social Forestry,

3. Decree of the Governor of Bali Number 2017/03-L / HK / 2015 concerning Village Forest Management,

4. Regulation of Bali Governor Number 75 of 2018 concerning Social Forestry,

5. Article (Pawos) 71 and 72 Traditional Village Awig-Awig of Pandan Banten Selat Village.

b. The effectiveness of BUMDesa authority in village forest management in the Selat Village of Buleleng has not been effectively implemented in accordance with the Village Forest Rights and Management of Work Plan and legislation that applies both state law and customary law. This is caused by several factors:

1. the unavailability of adequate human and capital resources for the management of all village forest areas,

2. lack of the assistance from technical agencies regularly and continuously to facilitate village forest managers to consult about village forest management patterns,

3. The absence of an appropriate and efficient marketing scheme for marketing village forest products, both non-timber products and ecotourism services.

\section{References}

[1] Borgias, S. L. (2018). "Subsidizing the State:" The political ecology and legal geography of social movements in Chilean water governance. Geoforum, 95(April 2017), 87-101. https://doi.org/10.1016/j.geoforum.2018.06.017

[2] Kan, K. (2016). The transformation of the village collective in urbanising China: A historical institutional analysis. Journal of Rural Studies, 47, 588-600. https://doi.org/10.1016/j.jrurstud.2016.07.016

[3] Soltani, A., Sankhayan, P. L., \& Hofstad, O. (2016). Playing forest governance games: State-village conflict in Iran. Forest Policy and Economics, 73, 251-261. https://doi.org/10.1016/j.forpol.2016.09.021 
[4] Susanto, A. F. (2015). Penelitian Hukum Transformatif-Partisipatoris. Malang: Setara Press.

[5] The 1945 Constitution of the Republic of Indonesia

[6] Awig-Awig of Selat Pandan Customary Village Banten of Sukasada Buleleng Regency.

[7] Bali Governor Regulation Number 75 of 2018 concerning Social Forestry.

[8] Government Regulation Number 72 of 2005 concerning Villages

[9] Government Regulation Number 6 of 2007 concerning Forestry Planning

[10] Government Regulation Number 24 of 2010 concerning Use of Forest Areas.

[11] https://ejournal.warmadewa.ac.id/index.php/csj/article/view/878, accessed March 21, 2019.

[12] https://www.hukumonline.com/klinik/detail/cl2861/legal-audit/, accessed on March $27,2019$.

[13] Interview with I Ketut Mangku, Chair of Selat Village Bumdes, Buleleng Regency on June 13, 2018, in Selat Village, Buleleng Regency.

[14] Interview with Wayan Semadi, Acting Selat Village Perbekel, Buleleng Regency on March 28, 2019.

[15] Law Number 41 of 1999 concerning Forestry

[16] Law Number 6 of 2014 concerning Villages

[17] Regional Regulation of Buleleng Regency Number 10 of 2015 concerning the Formation and Management of Village-Owned business entity.

[18] Regulation of the Minister of Environment and Forestry Number P.83/MENLHK /SETJEN/KUM.1/10/2016 concerning Social Forestry.

[19] Regulation of Minister of Home Affairs No. 39 of 2010 concerning Village-Owned business entity.

[20] Regulation of Selat Village No. 1 of 2011 concerning Village Forests.

[21] Regulation of Selat Village No. 2 of 2011 concerning Guidelines for the Establishment of Village-Owned business entity.

[22] Regulation of Selat Village No. 3/2012 concerning Pandan Harum Village Owned business entity. 